\title{
RESISTANCE OF LOCAL BANANA VARIETIES TO FUSARIUM WILT DISEASE
}

\author{
Mariana, Ismed Setya Budi \\ Department of Plant Protection, Faculty of Agriculture \\ University of Lambung Mangkurat, Banjarbaru, Indonesia \\ Email: mariana@unlam.ac.id
}

\begin{abstract}
Fusarium wilt is one of the important banana diseases that lead to low quality and quantity of banana production. The objective of this study was to examine and study the resistance of some local banana varieties to fusarium wilt. Pathogens were isolated from the weevil of kepok banana (saba banana) that showed severe symptoms of Fusarium wilt. The inoculum was prepared by propagating the pathogens on Potato Dextrose Agar (PDA) medium. Inoculation was carried out using mycelium fragment suspension (12 mg hyphae $\mathrm{mL}^{-1}$ tween $200.05 \%$ ). The roots of the twoweek Ambon banana were injured and immersed in the suspension. Pathogens were determined using Koch's postulates. The varieties tested were seven (7) local banana varieties grown in South Kalimantan. Levels of resistance were determined based on the scale of Leaf Symptom Index (LSI). The pathogens were identified as Fusarium oxysporum f.sp. cubense. The results showed that there were differences in the levels of resistance; Kepok banana (highly susceptible); yellow Ambon, Awa, Susu, Mahuli and Talas bananas (susceptible), and Manggala banana (tolerant).
\end{abstract}

Keywords: fusarium wilt, local bananas, resistance

\section{INTRODUCTION}

Fusarium wilt disease of banana is often called Panama disease caused by Fusarium oxysporum f. sp. cubense (FOC). It is a deadly, dangerous disease in addition to bacterial wilt. The disease has almost been spread in all countries producing bananas. It is suspected that the disease originated in Southeast Asia. The disease distribution in space and time is related to the prevalence of cultivars within the region and their resistance response. This disease can cause loss of more than $35 \%$ $50 \%$. The pathogens were transmitted through soil, attacked the roots and got into the banana weevil. In the banana weevil, the fungi damage the vessels, causing plants to wilt and eventually die (Poeltz, 2001).

Indonesia is one of the major centers of banana diversity. More than 200 types of bananas are in Indonesia. In South Kalimantan, there are nine types of bananas that grow luxuriantly and are cultivated (Nisa et al., 2010). This high diversity of bananas provides opportunities for Indonesia to utilize them as the sources of resistance genes to withstand the attacks of diseases including Fusarium wilt. The test of local banana resistance to banana diseases was intended not only to develop the resistant varieties but also to save the biological wealth of banana germplasms from the invasion of unwise disease-controlling technologies using chemical pesticides. This study was conducted to test the resistance level of several local banana varieties in South Kalimantan to fusarium wilt disease.

\section{MATERIALS AND METHODS}

\section{Survey of Disease Intensity}

The survey was conducted in four central locations of banana plantations in South Kalimantan. The intensity of the disease was observed in plant samples collected based on conditional random sampling (Delp et al., 1986). The intensity of the disease was calculated using the Abbot formula (1925 in Unterstenhofer, 1976).

Note:

$$
\mathrm{P}=\frac{\mathrm{a}}{\mathrm{a}+\mathrm{b}} \times 100 \%
$$

$$
\begin{aligned}
& P=\text { intensity of disease } \\
& a=\text { number of sick plants } \\
& b=\text { number of healthy plants }
\end{aligned}
$$




\section{Identification of pathogens causing the disease}

Before carrying out the identification of pathogens, the causes of the disease were determined using the Test of Koch's postulates. First, the pathogens were isolated by growing the culture of pathogens by following the instructions of the Fusarium Laboratory at Pennsylvania State University and the University of Sydney Australia (Singleton et al., 2001). Next, the pathogen isolates, the results of the isolation from the parts of symptomatic plants, were inoculated by soaking the banana roots that had been injured in mycelium fragment suspension (12 $\mathrm{mg}$ hyphae $\mathrm{mL}-1$ tween $20 \quad 0.05 \%$ ) (Modification, Mohammed et al., 2006). The isolates showing the ability to cause the symptoms similar to the initial symptoms were then reisolated to study the morphology of mycelium and spores like color, shape and size. When tested with Koch's postulates, the incubation period and developmental stages of symptoms were observed. The isolates able to
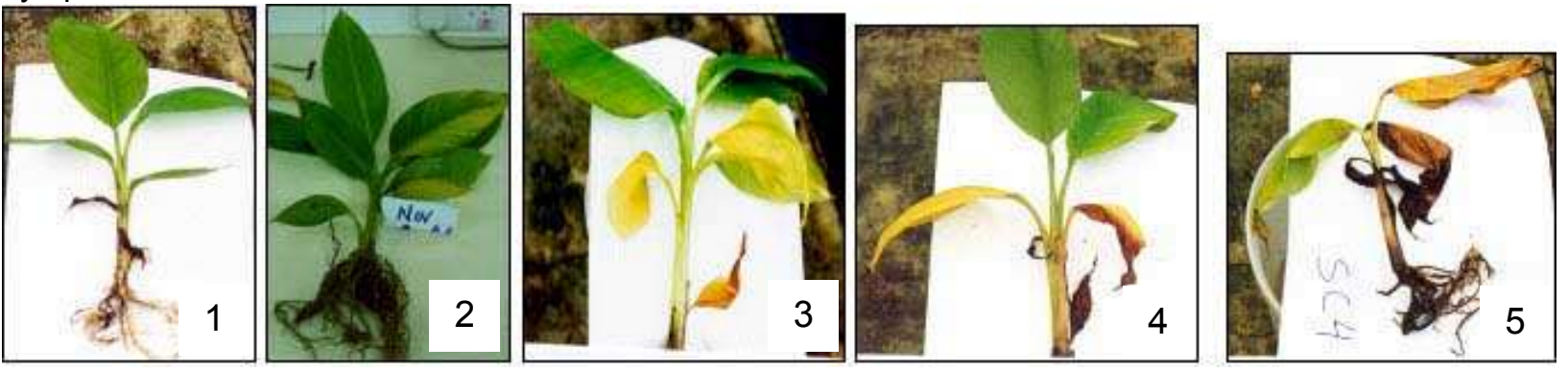

Scales:

1. No rot on the stem or yellowing of leaves, and plant looks healthy.

2. A bit rot on the stem and or yellowing on the lower leaves.

3. Rot on the stem and or yellowing on most of the lower leaves.

4. Severe rot on the stem or yellowing on most or all of the leaves.

5. Dead plant.

Figure 3. Scales of leaf symptom index (LSI)

After the calculation of LSI, the calculation of Disease Severity Index (DSI) was performed:

Table 1. Categories of resistance for LSI scales

\begin{tabular}{cc}
\hline DSI for LSI Scale & Resistance Category \\
\hline Between 1.1 and 2 & Resistant \\
Between 2.1 and 3 & Tolerant \\
Between 3.1 and 4 & Susceptible \\
\hline
\end{tabular}




\section{RESULTS AND DISCUSSION}

Based on the observations at several central locations of banana cultivation in South
Kalimantan, it was found out that there was no area free of Fusarium wilt disease and data showed that the intensity of attacks ranged between $11-61 \%$ (Table 1 ).

Table 2. Percentage of attack intensity of fusarium wilt at several locations of observation

\begin{tabular}{|c|c|c|c|c|c|c|}
\hline \multirow{3}{*}{$\begin{array}{c}\text { Area } \\
\text { (Regency) }\end{array}$} & \multicolumn{6}{|c|}{ Intensity of attack (\%) } \\
\hline & \multicolumn{6}{|c|}{ Location of observation } \\
\hline & $\mathrm{I}$ & II & III & IV & $\mathrm{V}$ & Mean \\
\hline Hulu Sungai Tengah & 35 & 20 & 14 & 19 & 34 & 24.4 \\
\hline Banjar & 21 & 43 & 24 & 25 & 13 & 25.2 \\
\hline Tanah Laut & 45 & 67 & 22 & 24 & 61 & 43.8 \\
\hline Kota Baru & 25 & 15 & 11 & 25 & 41 & 23.0 \\
\hline Average & & & & & & 29.1 \\
\hline
\end{tabular}

The results of survey at the four (4) locations of banana cultivation in South Kalimantan showed that in general the average percentage of the intensity of fusarium wilt disease in banana plants grown in South Kalimantan was $29.1 \%$. The highest intensity was $43.8 \%$ in Handil Gayam village, Kurau subdistrict, Tanah Laut Regency. The lowest intensity was $23.0 \%$ in Kotabaru Regency. The difference in the disease intensity in each regency was in accordance with the opinion of Hadiastono (2001) and Shull and Hamer (1994) stating that pathogens are always found in plants with different disease intensities, depending on the place and season. The progression of the disease has a close relationship with the condition of the environment as a place of life. The different conditions of environment also change the pathogens living in the system.

\section{Identification of Pathogens}

Pathogens were isolated from the plants showing outward symptoms, such as brown color in the stem and dark yellow (wilting) on the bottom edge of the leaves that spread quickly to the inside making the entire surface of the leaves yellow. Petioles had fractures at the base on the border with the fake stem (around the fake stem) (Figure 1a). The results of the symptom observation in the inside part of banana plants infected by Fusarium oxysporum f.sp. cubense showed that the color of the infected stem was reddish brown, and some produced bad odor while others did not (Figure 1b). The symptom in the weevil was the blackish brown color (Figure 1c). This is consistent with the results of the research by Rishbeth in Booth (1971) indicating that there are FOC fungi in the fake stem and weevil of banana and the interactions between fungi and plants result in odors (odoratum), but other interactions do not produce odors (inodoratum). In addition, pure isolates of the pathogens were isolated from soil in the rhizosphere of sick plants.

The results of FOC isolation from four local banana varieties (Talas, Mahuli, Awa, Kepok) was a colony of FOC with mauve to deep purple in color (Figure 1e). This is in accordance with the instructions of Booth (1971) in his book The genus of Fusarium, that most of FOC has somewhat purple-colored mycelium. In general, the colony pigmentation in Fusarium depends on the variation of light obtained by each species. F. decemcellulare reproduces more colors in the dark rather than in the light, although most of the pigmentation formation happen in the light. Additionally, the pigmentation is significantly influenced by the $\mathrm{pH}$ of the medium although some species have the ability to change the $\mathrm{pH}$ of medium. Sebek (1992) showed that f.oxysporum f.sp. lycopersici grew at a $\mathrm{pH}$ of $2.7-7.2$ while f.oxysporum f.sp. vasinfectum at a $\mathrm{pH}$ of 1.4 7.5 , and would produce abundant pigmentation at a pH of $2.7-4.5$ and little pigmentation at a $\mathrm{pH}$ of $6-7$. 

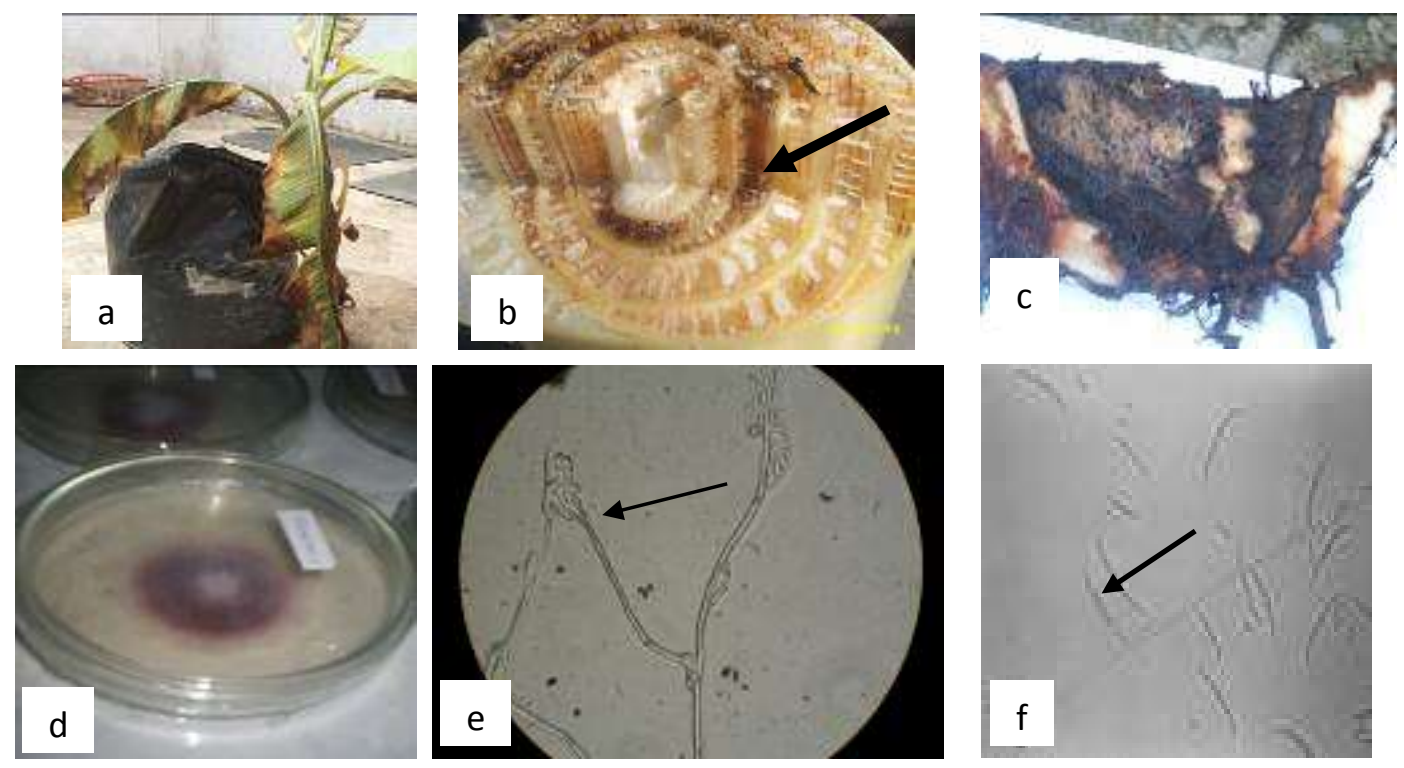

Figure 1. Identification of Fusarium wilt pathogens in banana. (a) Plants with wilt symptom. The part of plant isolated. (b) Symptomatic banana stem. (c) Symptomatic weevil. (d) Pure culture of Fusarium oxysporum f. sp. cubense. (e) Microscopic form of Fusarium oxysporum f. sp. cubense. (f) Macroconidium form of Fusarium oxysporum f. sp. cubense.

The results of the observation by growing the culture for identification, following the directions from the Fusarium Laboratory at the Pennsylvania State University and the University of Sydney Australia (Singleton et al., 2001) showed that the microscopic observation of microconidium (Figure 1e) is microconidium growing at the lateral end of conidiophores, branched conidiophores, with the average length of $70 \mu \mathrm{m}$. Conidium was formed on the main branch or side branch. Microconidium is one or two-celled, hyaline, ellipsoid shaped or slightly elongated, measuring 5-12 x 2.2-3.5 $\mu \mathrm{m}$. Microconidium crescent (Figure 1f) is 4celled, and hyaline. The results of Koch's postulates test confirmed that the pathogens causing the banana wilt symptoms were identified as Fusarium oxysporum f. Sp. cubense.

\section{Test of Plant Resistance}

The results of the resistance test of eight banana types, namely yellow Ambon, Mahuli, Kepok, Manggala, Thailand (Cavendish), Talas, Awa, and Susu, can be seen in Table 3 and Figure 2. The Manggala banana was included in 'tolerant' category. However, in South Kalimantan, the Mangala banana has not been cultivated probably because this variety is a table banana type that is generally eaten directly and has less favored taste. Therefore, it is necessary to do further research utilizing this banana as a source of plant resistance to Fusarium wilt of banana. The Kepok banana, the local variety most produced among other varieties, turned out to be highly susceptible, while other four local varieties (Mahuli, Awa, Susu and Talas) were susceptible. 
Mariana, Ismed Setya Budi: Resistance Of Local Banana Varieties To Fusarium Wilt Disease.

Table 11. Response of 8 (eight) banana varieties to $F$ oxysporum f. sp. cubense

\begin{tabular}{lcc}
\hline \multicolumn{1}{c}{ Variety } & LSI Scale & Resistance category \\
\hline Yellow Ambon (resistance check) & 2.3 & Susceptible \\
Kepok & 3.1 & Highly susceptible \\
Mahuli & 2.5 & Susceptible \\
Awa & 2.3 & Susceptible \\
Talas & 2.8 & Susceptible \\
Susu & 2.2 & Susceptible \\
Manggala & 1.2 & Tolerant \\
Thailand (cavendish) resistance check & 1.1 & Tolerant \\
\hline
\end{tabular}
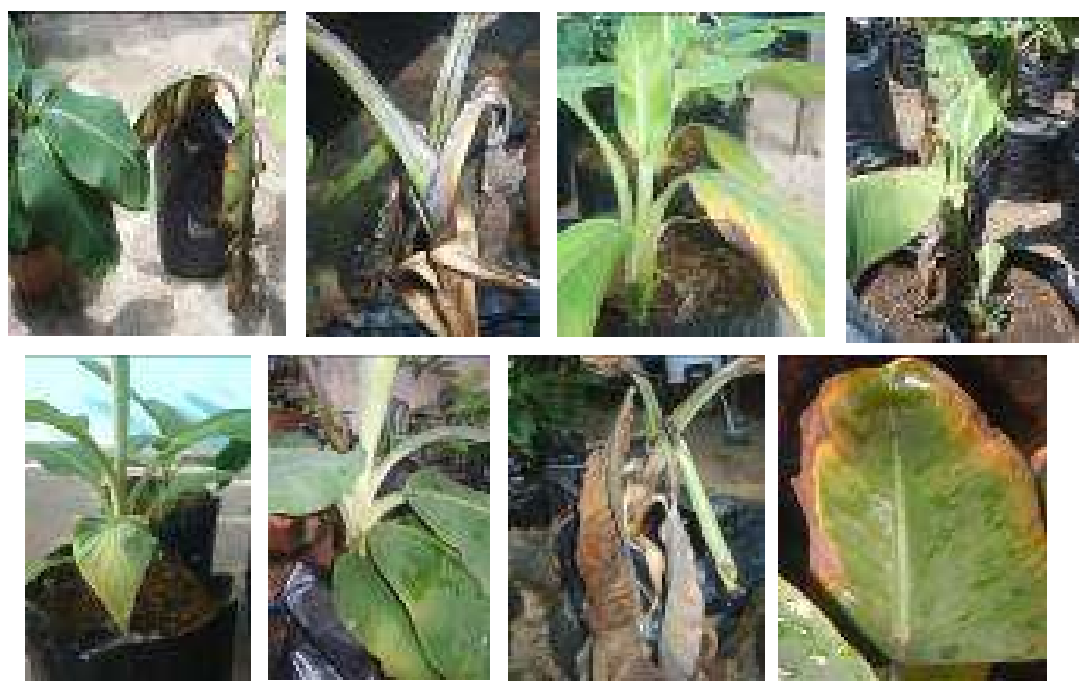

Figure 2. Response of tested varieties to FOC pathogens

\section{CONCLUSIONS}

It can be concluded that the cause of wilt disease in the banana plants was Fusarium oxysporum f. sp. cubense. Most of the local varieties observed were susceptible to fusarium wilt, namely Mahuli, Awa, Susu and Talas, and even the Kepok banana was highly susceptible, but the Mangala banana was tolerant.

\section{REFERENCES}

